\title{
Optimering af informationsarkitekturen i FN's World Food Programme
}

\author{
Af Haakon Lund \& Susanne Ørnager
}

\begin{abstract}
FN' fødevareprogram World Food Programme ønskede en forbedret informationsarkitektur. Artiklen beskriver et casestudie hvor WFP's information-og vidensstyring undersøges herunder analyse af brugernes (WFP's medarbejderes og -frivilliges) søgninger og WFP's informationsarkitektur generelt. I artiklen prcesenteres en rckke metoder til at identificere problemerne i organisationen. Resultaterne viser, at udviklingen og implementeringen af en folles taksonomi kan minimere ulemperne ved navigation og søgning efter information og dokumenter vha. de etablerede søgemaskiner.
\end{abstract}

Konklusionen er, at der dels skal udvikles en emneordsliste, der sikrer en ensartet terminologi i hoved$k v a r t e r e t$ og på samtlige landekontorer, og dels at der skal udvikles et system af synonymringe, der gør informationssøgning langt mere effektiv. For at sikre den fremtidige effekt af disse tiltag anbefales det, at der udncevnes en person med centralt ansvar samt en rakke lokale eksperter, taksonomi champions, til fortsat at udvikle og vedligeholde informationsarkitekturen. De sidstncevnte anbefalinger er blevet implementeret af WFP.

Haakon Lund, Lektor, Det Informationsvidenskabelige Akademi, Københavns Universitet

hl@hum.ku.dk

Susanne Ørnager, PhD, Lektor, Det Informationsvidenskabelige Akademi, Københavns Universitet fpm434@hum.ku.dk

\section{Introduktion}

FN's fødevareprogram World Food Programme (WFP) ønskede fra foråret 2013 etablering af en forbedret informationsarkitektur til WFP på tværs af lande og kulturer. Det blev udgangspunkt for et casestudie. Informationsarkitektur skal her forstås som en intranetstruktur, der bl.a. inkluderer metadata, navigationsmønstre, søgefaciliteter og organisation af arkiv og administrative systemer. En vigtig komponent ved oprettelsen af en effektiv informationsarkitektur er desuden en virksomhedstaksonomi (Gilchrist, 2001; Gilchrist, 2003; Chaudhry \& Jiun, 2005).

WFP er den største af FN's organisationer med ca. 14.000 ansatte på verdensplan. Hovedparten af de ansatte er placeret i ca. 80 lande- eller regionalkontorer (felten) og små 1200 er i hovedkontoret i Rom. Organisationens mål er at levere nødhjælp i form af mad til ofrene for naturkatastrofer, krig og hungersnød og i tillæg at hjælpe lokalsamfund med opbygningen af deres infrastruktur efter katastrofer. I 2013 hjalp WFP omkring 81 millioner mennesker. I 2014 modtog WFP ca. 30 milliarder kroner, og af disse var Danmarks biddrag 439 millioner kroner. WFP's fokus er altså på nødhjælp, og informationshåndtering ses ikke som et kerneområde. Imidlertid oplevede de ansatte en stigende frustration, fordi det var utrolig tidskrævende og anstrengende at finde relevant information i nødhjælpssituationer, og samtidig ønskede administrationen en fælles terminologi og en bedre videndeling i organisationen. Utilfredsheden med den vanskelige tilgang til information resulterede $i$, 
at mange lande- og regionalkontorer opbyggede egne systemer, så WFP var i en situation med mange enkeltstående systemer - de såkaldte "silo-enheder" - i tillæg til det tungt fungerende fællessystem. Informationsordbogens (2015) definition af informationsarkitektur:

"... et område, der beskæftiger sig med at designe klare, forståelige informationer ved at være omhyggelig med at tage hensyn til struktur, kontekst og præsentation af data. Termen er mest knyttet til design af websider, men kan også mødes i andre kontekster".

Ovenstående afdækning af problemområder i den eksisterende informationsarkitektur leder hen til forskningsspørgsmålet for undersøgelsen. Med baggrund i de opridsede omstændigheder er de overordnede problemer brobygning mellem brugere og informationsindhold, mellem platforme og informationskanaler og mellem forskning og praksis. Opgaven blev at gøre klart for WFP, hvordan de enkelte delelementer forholder sig til helheden i organisationen, og hvorledes dette kan adresseres i en informationsarkitektur.

Det grundlæggende forskningsspørgsmål kan på denne baggrund formuleres:

At betragte informationsarkitekturen for WFP på et overordnet organisatorisk plan, hvor det ikke kun indebærer at udvikle organisationssystemer og -strukturer for et intranet, men også at etablere en fælles terminologi og en virksomhedstaksonomi for hele den globale organisation.

For at operationalisere det opstillede forskningsspørgsmål kan der opstilles 3 undersøgelsesspørgsmål som samtidigt fungerer som retningsgivende $\mathrm{i}$ forhold til valg af dataindsamlingsmetoder:

1. At bidrage til etablering af en fælles terminologi og en fælles forståelse i hele organisationen af information management og knowledge management, $d v s$. håndtering af viden.

2. At analysere brugernes (WFP's medarbejderes og frivilliges) søgninger efter og adgang til information ved hjælp af såvel intranet som internet.

3. At analysere WFP's informationsarkitektur og levere anbefalinger til en ny struktur, der vil gøre det muligt for brugerne hurtigt at finde den viden, de har brug for. Dette stiller krav til registrering af information, navigationsstruktur på intra- og internet samt et effektivt og entydigt kategoriseringssystem, en taksonomi.

\section{Metode}

Artiklen er et casestudie, hvor en række forskellige dataindsamlingsmetoder er anvendt. Casestudiet blev valgt som metode, da det derved har været muligt at udføre undersøgelsen med et mindre antal respondenter, hvor de forskelligartede dataindsamlingsmetoder eller triangulering af dataindsamlingsmetoder kompenserer for antallet af respondenter (Lazar, Feng \& Hochheiser, 2010).

De anvendte dataindsamlingsmetoderne er veldokumenterede og afprøvede indenfor det informationsvidenskabelige felt (Hyldegård et al. 2011). Case studiet er opdelt i 3 faser, som følger de opstillede undersøgelsesspørgsmål, og der er til hver fase knyttet en række dataindsamlingsmetoder:

Første fase er en dokumentarisk undersøgelse (Evers, 2009) med fokus på forskellige forståelser af Knowledge Management (KM) og Information Management (IM), samt en semi-struktureret interviewundersøgelse (Kvale, 2009, s. 135), hvor interviewene rettede sig mod de ansatte i forskellige afdelinger i hovedkvarteret i Rom (undersøgelsesspørgsmål 1). Interviewene blev gennemført i april 2013.

Anden fase er en kvantitativ log-fil analyse af WFPgo (WFP's intranet) søgelog fra september til november 2013 (Janssen, 2009) og dataindsamling vha. semi-strukturerede interviews af WFP ansatte i felten (Telefon interviews) (Kvale, 2009, s.135) og i hovedkvarteret i Rom (undersøgelsesspørgsmål 2).

Tredje fase er workshops for de ansatte i hovedkvarteret, bl.a. om KM/IM og taksonomi, hvor der i sidstnævnte blev anvendt en kortsorteringsøvelse (Morville \& Rosenfeld, 2007) understøttet af observationer af brugerudsagn. Workshop afholdt $\mathrm{i}$ januar 2014 (WS1) samt april 2014 (WS2) og en workshop om søgemaskiner og behovet for metadata afholdt i april 2014 (WS3). De sidste metoder dækker undersøgelsesspørgsmål 3 .

WFP er en stor organisation geografisk spredt på hele kloden. Af praktiske hensyn blev de dele af da- 
taindsamlingen, som indebar involvering af ansatte $i$ WFP fortrinsvis foretaget med ansatte i hovedkvarteret i Rom. Enkelte interviews kunne dog afvikles som telefoninterviews med ansatte i udvalgte landekontorer. Regionalkontorerne er repræsenteret $\mathrm{i}$ søgelog-filanalysen, som omhandler hele organisationen. Overordnet kan siges, at WFP's politik, der siger at alle ansatte skal søge job i et WFP kontor udenfor hovedkvarteret efter fire år, er med til at sprede viden $i$ hele organisationen og dermed mindske tendensen til, at hovedkvarteret dikterer løsningsmodellerne.

Den resterende del af artiklen følger i sin opbygning de beskrevne faser.

\section{Informations- og videndeling (fase 1)}

Knowledge Management (KM) og Information Management (IM) defineres forskelligt af forskellige forskere/organisationer, og der eksisterer også forskellige definitioner inden for WFP, dvs. at man ikke arbejder med samme forståelsesniveauer i organisationen om KM og IM, deres roller og vigtighed. For WFP er det interessant at få belyst, hvordan tilsvarende organisationer, forskere og konsulentfirmaer har defineret og/eller beskæftiget sig med KM og IM.

International Fund for Agricultural Development (IFAD), som er en søsterorganisation til WFP, skrev i 2007 i deres strategidokument om KM at:

"It is also clear from IFAD's own experiences and those of others that the key to success in knowledge management is to ensure that all aspects of it are built on and tightly embedded in an organization's work processes and products." (IFAD, 2007, s. 17).

IFAD ser altså KM som bestående af processer og produkter designet til at erhverve og dele intellektuel viden baseret på aktiver i organisationen og i de enkelte lande. Her understreges det, at KM er en nødvendig del af processer og produkter i en organisation. IFAD's strategi gælder stadig som grundlag for $\mathrm{KM}$, idet viden ses som en vigtig ressource til at bringe et land ud af fattigdom (IFAD, 2011, s. 6).

Daniel E. O'Leary (2008, s. 642) som undersøgte KM i FAO (Food and Agriculture Organization) skriver:
"While providing appropriate knowledge "content," some of the key functions of a knowledge management (KM) system include "converting" and "connecting" knowledge ... Content includes a broad range of resources, such as knowledge about how to solve particular problems ("things gone right") or knowledge about how to not solve problems ("things gone wrong")."

Her er fokus på erfaringsudnyttelse, hvilket kan relateres til både processer og produkter som anført i IFAD's strategi.

Verdensbanken, som er hovedlångiver til udviklingslande, har i en publikation om opretholdelse af lokalsamfund defineret KM som følger: "The World Bank's knowledge management approach has steadily evolved away from the idea of knowledge management as a product and towards the idea of knowledge management as an activity generating solutions" (APQC, 2010, s. 2). Udtalelsen står i modsætning til IFAD's tilgang, idet der lægges op til en forståelse af KM, som er mere løsningsorienteret, men ikke ser produkter som en del af KM.

Koenig (2012) refererer til tidlige definitioner af KM og skriver, at da man begyndte at beskæftige sig med KM var Davenport (1994) en af de første forskere, der udformede en definition, som stadig anvendes:

"Knowledge Management is the process of capturing, distributing, and effectively using knowledge."

Denne definition er ifølge Koenig procesorienteret og meget målrettet, og den lægger i øvrigt tidligt op til Verdensbankens definition ovenfor.

Få år senere giver Gartner Group ${ }^{1}$ ifølge Koenig en anden definition af KM, som er baseret på Duhon (1998)

"Knowledge Management is a discipline that promotes an integrated approach to identifying, capturing, evaluating, retrieving, and sharing all of an enterprise's information assets. These assets may include databases, documents, policies, procedures, and previously un-captured expertise and experience in individual workers." 
Også denne definition er procesorienteret. Gartner Group ændrer den i 2015 til:

"Knowledge management (KM) is a business process that formalizes the management and use of an enterprise's intellectual assets. KM promotes a collaborative and integrative approach to the creation, capture, organization, access and use of information assets, including the tacit, un-captured knowledge of people." (Gartner IT Glossary, 2015).

Den nuværende definition ser på erhvervslivets forskellige processer og understreger samarbejde i forhold til informationsadgang og "tacit" viden.

Alle definitioner og udtalelser er meget organisationsrettede, og nogen omfatter både processer og produkter, medens andre koncentrerer sig om processerne. Historisk set kan KM defineres som administration af viden i og om organisationer, men som Gartner Group, Verdensbankens og IFAD's forskellige strategier viser, er der ikke fuld enighed om en fælles definition. En præcisering af én fælles definition bør udarbejdes af WFP under hensyntagen til, hvad organisationerne indenfor det samme faglige område mener/definerer KM som.

Problemet med den fælles forståelse i WFP er ikke kun relateret til KM, også IM opfattes forskelligt i organisationen. Informationsordbogens (2015) definition af IM henviser til informatik, der defineres som:

"Disciplin der studerer informationsforløb, informationssystemer, informationshåndtering (overføring, lagring, nyttiggørelse) hovedsagelig - men ikke nødvendigvis - med computere og telekommunikationsudstyr som værktøjer."

I definitionen opregnes flere områder, som IM dækker, men fælles for denne og flere beskrivelser af IM er, at information betragtes som en ressource (Bawden \& Robinson, 2012, s. 253) og at denne "ressource" håndteres vha. IT

Gartner Groups definition fra 2015 understreger dette, idet de skriver om IM:

"A method of using technology to collect, process and condense information with a goal of efficient management. Most large enterprises have a cen- tral IM function to facilitate this coordination ..." (Gartner IT Glossary, 2015).

De to beskrivelser af IM taler om koordinering og integration af en lang række informationshandlinger og om informationssystemer og teknikker. Information bliver altså opfattet som en ressource, der af nogen ses som en undergruppe til KM, en undergruppe der især beskæftiger sig med teknologi. For at få en mere detaljeret/nuanceret definition af IM, må der ses på in- og eksterne aktiviteter i organisationen, der kan inkludere formuleringen af organisationens informationspolitik, design, information og data (Howe, 2010).

For at udvikle både en fælles KM og IM strategi bør der også tages udgangspunkt i de ansattes vidensniveau (hvad har de ansatte brug for?), og det er relevant at undersøge, hvilke typer viden der er i organisationen (hvad er allerede tilgængeligt?). De ansattes behov sammenholdt med den interne oversigt over tilgængelighed kan identificere både behov og tilgængelighed.

Anden del af undersøgelsen er baseret på en semistruktureret interviewform, som er meningskondenseret, involverende ansatte fra WFP Library (2 respondenter), the Executive Board (3 respondenter), the Information Technology (IT) Division (1 respondent) og the Business Innovation and Support Office (1 respondent). Interviewene blev foretaget i de pågældende afdelinger. Interviewspørgsmålene var overordnede og åbne, idet målet var at få et overblik over WFP's forståelse af KM og IM i de forskellige afdelinger. De ansatte blev som gruppe alene spurgt om, hvor længe de havde været ansat, hvad de forstod ved KM og IM, og om de kunne definere forskellen på KM og IM.

De generelle udsagn var, at WFP er en organisation med meget lidt erfaring i systematisk KM og IM. De specifikke udsagn var mere nuancerede, som det fremgår af nedenstående.

De ansatte i Biblioteket udtalte bl.a. at:

"While WFPgo (intranet) is a useful tool for internal communication, major improvements would be needed to make it become a platform for systematic access to information and knowledge management." 
Biblioteket er altså klar over WFPgo's (ITs) tilgængelighed, men de ansatte oplever ikke, at deres genfindingsbehov tilgodeses. Der er altså utilfredshed med IT systemet, men bibliotekets ansatte berørte ikke, hvordan IM forstås i WFP, og i løbet af interviewet kom det heller ikke tydeligt frem, hvad biblioteket egentlig forstår ved KM.

Ansat i IT - afdelingen anførte bl.a. at:

"... there are areas of data collection and information management and knowledge sharing, and the IT Division has responsibility in both areas. While the generation and sharing of information are the joint responsibility of all WFP units, the IT Division is in charge of creating, maintaining and improving systems and tools to facilitate access, retrieval and sharing of information."

IT afdelingens udtalelse drejer sig overvejende om indsamling og tilgængeliggørelse af data, de interviewede berører også anvendelse af information (IM), men giver ikke noget klart bud på videnshåndtering (KM). IT afdelingen fokuserer på deres egen service/ formidlerrolle, som de er opmærksomme på også at definere. Der kan være et problem mellem de ansattes behov for kommunikation og tilgængeligheden, og IT afdelingens definering af samme. Selvom interviewet klart var fokuseret på kommunikation, var IT afdelingen meget åben over for en fælles forståelsesramme for IM og KM.

Den ansatte i kontoret for Business Innovation and Support udtalte bl.a.:

"As part of an effective knowledge management, a content management strategy would be needed that qualifies and classifies information of corporate relevance according to a corporate taxonomy and information architecture."

Bemærkningen viser, at kontorets ansatte er bevidste om, hvad en KM og IM strategi kan indebære, hvilket også bliver understreget af følgende udsagn:

"For a corporate information and knowledge management strategy, the scope of investment in the WFP library would need to be redefined, as would be the role of the Regional Bureaus in a more and more decentralized organizational structure."
Der er altså en forståelse af, at en fælles strategi er nødvendig både på KM og IM områderne, dette gør sig især gældende med en større decentralisering af de regionale kontorer. Kontorets udtalelser tolkes som ønsket om en fælles definition og terminologi i WFP.

Ledelsen, repræsenteret ved ansatte i the Executive Board, udtalte bl.a.:

"In order to develop the WFP library into a platform for information and knowledge management, an integrated approach would be needed, supported by senior management."

Og videre

"From a technical point of view, a clear and stable information architecture, corporate taxonomy and strong search engine are key requirements for successful information management."

Bemærkningerne fra ledelsen indikerer, at WFP har behov for at udvikle af en fælles forståelse af KM og IM her udtrykt som udvikling af biblioteket til et videnscenter og udvikling af informationsarkitekturen. Spørgsmålet, om hvor længe de enkelte afdelingers personale havde været ansat, fungerede mest som en "ice breaking" indgang, idet det ikke gav nogen information om forholdet mellem længden af ansættelse og forståelsen af KM og IM.

Det andet spørgsmål, om hvad de ansatte forstod ved KM og IM, gav divergerende svar. Nogle afdelinger valgte at se på enkelte dele af KM og IM, medens andre pegede på udviklingen af en fælles definition. Kun en afdeling, kontoret for Business Innovation and Support, pegede på udviklingen af en "corporate information and knowledge management strategy" som løsning for hele WFP.

Det tredje spørgsmål om forskellen på KM og IM blev ikke helt besvaret. De ansatte i Executive Board talte om et "integrated approach", og det kan tolkes som IM værende en vigtig del af KM, men en decideret forskel blev ikke påpeget.

Konklusionen på fase $1 \mathrm{er}$, at organisationen skal stræbe efter en fælles definition for henholdsvis KM og IM, definitioner som på sigt anvendes af alle ansatte. For at opnå dette skal der formuleres en fælles 
terminologi og et sæt retningslinjer for udviklingen af WFP's strategi for administration af information og viden.

\section{Brugernes brug af eksisterende informationssy- stemer (fase 2)}

WFP anvender en række af informationssystemer:

\begin{tabular}{|l|l|}
\hline System & Anvendelse \\
\hline WFPgo & WFP intranet \\
\hline DocuStore & Dokument håndteringssystem \\
\hline LYNC & $\begin{array}{l}\text { Online corporate messenger } \\
\text { system }\end{array}$ \\
\hline $\begin{array}{l}\text { Microsoft SharePoint incl } \\
\text { Teamwork spaces }\end{array}$ & $\begin{array}{l}\text { Fælles arbejdsdrev og viden- } \\
\text { deling }\end{array}$ \\
\hline WINGS & $\begin{array}{l}\text { WFP corporate information } \\
\text { system }\end{array}$ \\
\hline EPweb & $\begin{array}{l}\text { WFP corporate system for } \\
\text { information management in } \\
\text { emergencies }\end{array}$ \\
\hline SAP & $\begin{array}{l}\text { Accounting system (data } \\
\text { warehouse) }\end{array}$ \\
\hline
\end{tabular}

Tabel 1. Informationsystemer anvendt $i$ WFP. Der findes endvidere en rakke systemer implementeret $i$ enkelt afdelinger

WFPgo er WFP's intranet og vises som standardside, når personalet i WFP åbner web-browser. Indholdet i WFPgo er søgbart. De ovennævnte informationssystemer kan tilgås fra WFPgo, men indholdet i systemerne er ikke søgbare via WFPgo søgefacilitet dog fraset udvalgte dokumenter fra dokumentsystemet DocuStore. Udover de nævnte informationssystemer findes der en række systemer som er implementeret af enkeltafdelinger.

Der blev i projektet gennemført en række semi-strukturerede interviews for at afdække, hvorledes WFPansatte tilgår information og viden og for at identificere eventuelle problemer med den eksisterende organisering af dokumenter og de anvendte systemer. I alt 10 interviews blev afholdt med ansatte fra 6 forskellige geografiske lokaliteter. Analysen af interviews er primært baseret på Davis' (1989) Technoloy Acceptance Model (TAM).). Davis opererer med 2 brugeropfattelser af et system "Percieved Usefulness" defineret som "the degree to which a person believes that using a particular system would enhance his or her job performance" (Davis, 1989, s.320).og "Percieved Ease of Use" defineret som "the degree to which a person believes that using a particular system would be free of effort" (ibid.) Ifølge Davis vil et systems percieved usefullness og percieved ease of use være determinerende for, hvorledes brugerne opfatter et system og dermed deres brug af systemet. Davis beskriver brugernes brug af et system som værende bestemt af brugernes tro på, at systemet kan hjælpe dem til at udføre deres arbejdsopgave bedre eller mere effektivt (percieved usefulness), men samtidigt vil brugerne forkaste brugen af et system, hvis systemet opfattes som værende for vanskeligt at anvende uagtet, at dette (system) vil hjælpe brugerne til optimere deres arbejdsopgaver (percieved ease of use) (ibid.). Ifølge TAM er percieved usefulness og percieved ease of use et udtryk for en ydre påvirkning af brugeren i form af eksterne variable f.eks karakteristika ved et system, træning i anvendelse af systemet, udviklingsprocessen af systemet. (Venkatesh \& Davis, 2000, s. 187). Ifølge TAM er percieved usefullness også influeret af percieved ease of use begrundet $i$, at et system, der opfattes som nemt at bruge, alt andet lige også vil opfattes som brugbart (ibid.). Interviewundersøgelsen afdækkede problemer hos respondenterne i deres brug af systemer. Respondenterne udtrykker vanskeligheder med at overskue WFPgo's organisering, hvilket gør navigation i WFPgo problematisk. Søgefunktionaliteten i WFPgo betragtes af flere som værende dårligt fungerende. Interviewene afslørede endvidere skepsis blandt brugerne i forhold til troværdigheden af fundne dokumenter i WFPgo. Brugerne fandt ofte dokumenter, som var forældede og derfor ikke relevante. $\mathrm{Ud}$ af 10 respondenter opgav 6 , at de ikke havde modtaget træning i anvendelsen af et eller flere af de systemer, de forventes at anvende. 2 respondenter angav, at de havde modtaget træning. 2 respondenter var ikke sikre.

Hvis vi ser på TAM-modellens kategorisering $\mathrm{i}$ percieved usefullness og percieved ease of use er respondenternes opfattelse af WFPgo negativ, hvad angår begge kategorier resulterende $\mathrm{i}$ en afvisning af WFPgo. Den negative opfattelse af WFPgo kan henføres til en række eksterne variabler såsom karakteristika ved WFPgo i form af problemer med den eksisterende informationsarkitektur i WFPgo, manglende retningslinjer for indholdsstyring resulterende forældede dokumenter samt manglende træning i anvendelse af system. Som en ydre variabel kan også næv- 
nes den manglende mulighed for at søge på tværs af de eksisterende informationssystemer, hvilket resulterer i et manglende overblik over hvilke information eller dokumenter der er tilgængelig i organisationen. Vi kan tale om siloer af information.

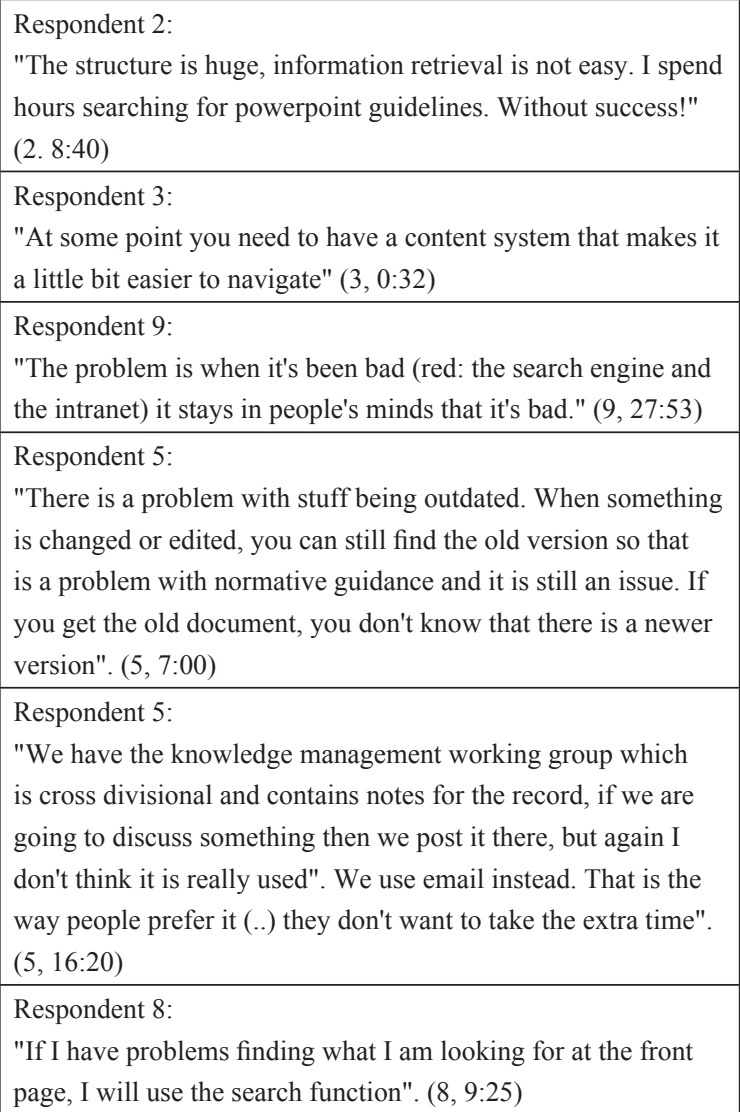

Tabel 2. Udsagn fra respondenter med eksempler på oplevede problemer $i$ brugen af WFPgo

For at uddybe de ovennævnte brugerudsagn analyserede vi søgeloggen fra den implementerede søgemaskine (Google Search Appliance). Analyse af søgelogs fra Intranet søgemaskiner giver en indsigt $i$ brugernes søgetaktik (Jansen, 2009, s. 63), og de indsamlede logdata kan betragtes som adfærdsdata, der relaterer til brugernes adfærd i et web system (Jansen, 2009, s. 2). Broder (2002) identificerer tre typer af web søgninger:

- Navigational: Intentionen er at finde en specifik side
- Informational: Intentionen er at få informationer, som formodes at være til stede på en eller flere web-sider

- Transactional: Intentionen er at udføre en/flere web-medierede aktiviteter.

Søgelog fra perioden fra 1. september - 30. september 2013 for søgninger foretaget i regionalkontorer blev analyseret følgende Broders opdeling i typer af web-søgninger. I alt 1712 unikke søgning blev fundet. 741 søgninger kunne karakteriseres som tilhørende kategorien "Navigational" og dermed i nogen grad fungere som erstatning for navigation i WFPgo. Kategoriseringen af søgningerne jvf Broder er fortaget af en projektmedarbejder og derefter diskuteret med forfatterne.

\begin{tabular}{|c|c|c|}
\hline Søgestreng & $\begin{array}{l}\text { Antal } \\
\text { søgninger }\end{array}$ & Bemærkning \\
\hline "exchange rate" & 1341 & $\begin{array}{l}\text { Tallet for antal hits er en sam- } \\
\text { menlægning af de varianter, } \\
\text { der kunne identificeres fra } \\
\text { søgelog. Der findes en henvis- } \\
\text { ning i menu strukturen til en } \\
\text { side med "UN exchange rate" }\end{array}$ \\
\hline "search WFPgo" & 957 & Standard-tekst i søge-feltet \\
\hline $\begin{array}{l}\text { "generic job } \\
\text { profile" }\end{array}$ & 947 & $\begin{array}{l}\text { Sammenlægning af varian- } \\
\text { ter. Der findes et menu-punkt, } \\
\text { som giver adgang til side med } \\
\text { Genric job profile }\end{array}$ \\
\hline "LMS" & 569 & $\begin{array}{l}\text { Acronym for en afdeling som } \\
\text { også kan findes via navigati- } \\
\text { onsmenu }\end{array}$ \\
\hline "fit for purpose" & 547 & $\begin{array}{l}\text { Organisationen havde netop } \\
\text { gennemført et nyt organisato- } \\
\text { risk design, som var navngivet } \\
\text { "Fit for purpose", men også } \\
\text { en sundhedsundersøgelse un- } \\
\text { der samme navn. Søgningen } \\
\text { dækker formodentlig over en } \\
\text { blanding af begge, dog er } 3 \text { af } \\
\text { top } 10 \text { søgninger relateret til } \\
\text { sundhedsundersøgelsen. }\end{array}$ \\
\hline
\end{tabular}

Tabel 3. De 5 hyppigst forekommende søgeformuleringer $i$ WFPgo

Den mest almindelige fejl ved søgning er, at brugerne opnår 0 - hits i deres søgeresultat (Rosenfeld, 2011, s 62). Søgelog fra en tre måneders periode fra 
1. september -30 . november blev analyseret. I alt 102310 søgninger blev registreret i perioden, og af de udførte søgninger resulterede 7185 i 0-hits svarende til $7 \%$ af de registrerede søgninger. Dette resultat må forventes at bidrage til den usikkerhed, respondenterne $\mathrm{i}$ interviewundersøgelsen gav udtryk for $\mathrm{i}$ forhold til at finde information i WFPgo.

På baggrund af resultaterne fra de afholdte interviews er der identificeret en række faktorer, som påvirker respondenternes opfattelse af WFPgo negativt og i flere tilfælde betyder, at brugerne afviser at bruge systemet. En dårligt fungerende informationsarkitektur i form af problemer med organisering af navigationsstruktur, dårligt fungerende søgefunktionalitet og mangler i dokumentstyring kan nævnes. Problemer med navigationsstrukturen understøttes af log-fil analysen, hvor mange af de foretagne søgninger erstatter navigation.

\section{Udvikling af virksomhedstaksonomi (fase 3)}

En væsentlig forudsætning for at opnå den ønskede integration vil udover systemtilpasninger også være implementeringen af standardiserede meta-data inklusiv en fælles virksomhedstaksonomi. I WFP arbejdes med en værdikæde (figur 1), som afspejler organisationens struktur, og som er repræsentativ for de faser, ethvert nødhjælpsprojekt gennemløber. På et ledelsesseminar blev der foreslået en liste over "functions", som kunne anvendes til strukturering af WFP's viden (figur 2). En High Level Taxonomy (HLT) blev baseret på denne liste, hvor Operational functions kom til at indeholde termer som "evaluation, logistic, procurement \& security", Support Functions bestod af termer som "ICT, human ressources $\&$ innovation", og endelig var Themes and Cross Themes uden tilknyttede termer, så sådanne termer kan ændres i forholdt til aktuelle nødhjælpsprojekter i WFP. I forbindelse med værdikæden er HLT arrangeret således, at Support Functions og Cross Themes med samt deres termer kan placeres under alle fire elementer i kæden, idet de anses for aspekter altså den faglige synsvinkel en funktion/et tema ses fra, medens Operation Functions og de tilhørende termer

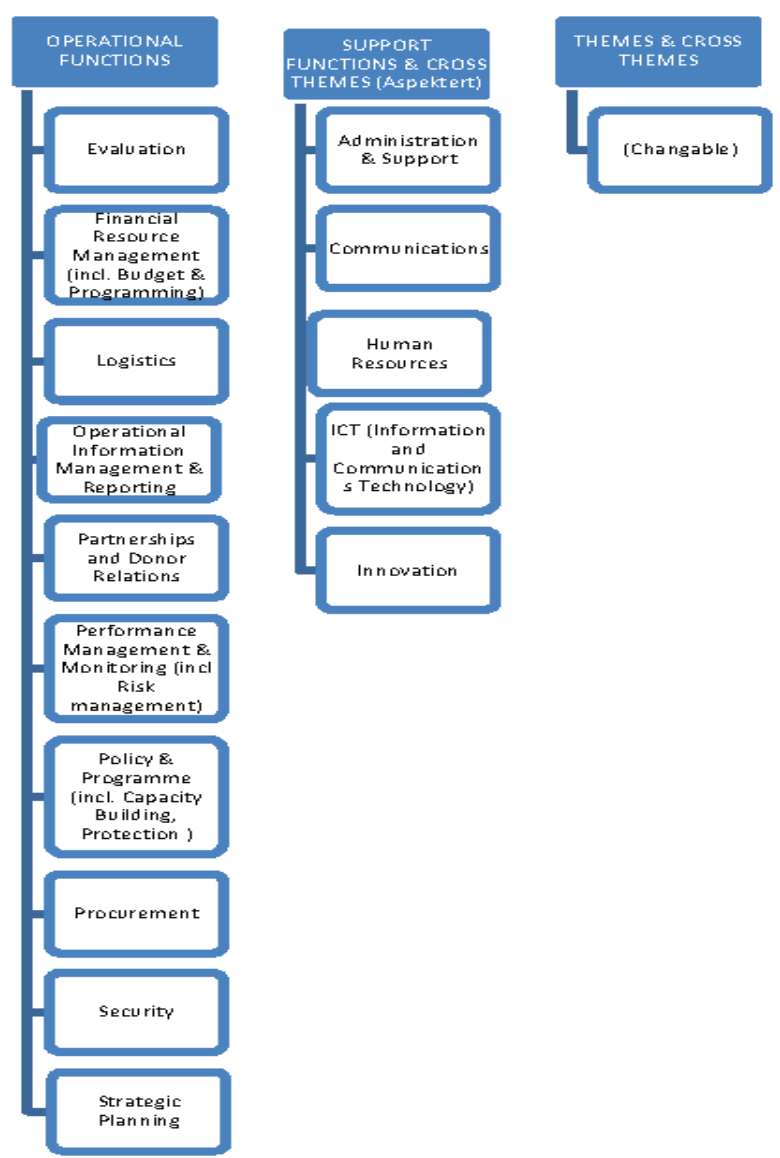

Figur 2. Første High Level Taxonomy (HLT)

på forhånd er blevet knyttet til et af elementerne i kæden f.eks. kan termen "evaluation" kun placeres under "Measure Result " i værdikæden.

Taksonomi bliver i litteraturen både defineret som et snævrere og et bredere begreb. I den snævrere betydning tales der om et hierarkisk klassifikations- eller kategoriseringssystem, og i den bredere betydning refereres til enhver opfattelse af organisation af viden (Hedden, 2010, s. 1). I en verdensorganisation som WFP, hvor informationslagret hele tiden vokser, må søgninger være velorganiserede og -strukturerede. Intranettet WFPgo er konstrueret i forhold til organisationsstrukturen dvs. afdelingerne i WFP. Denne ordning synes umiddelbart logisk, men der opstår

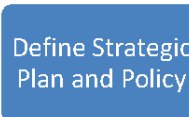

Figur 1. WFP vardikcede
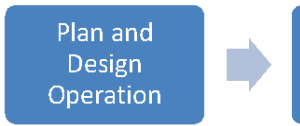


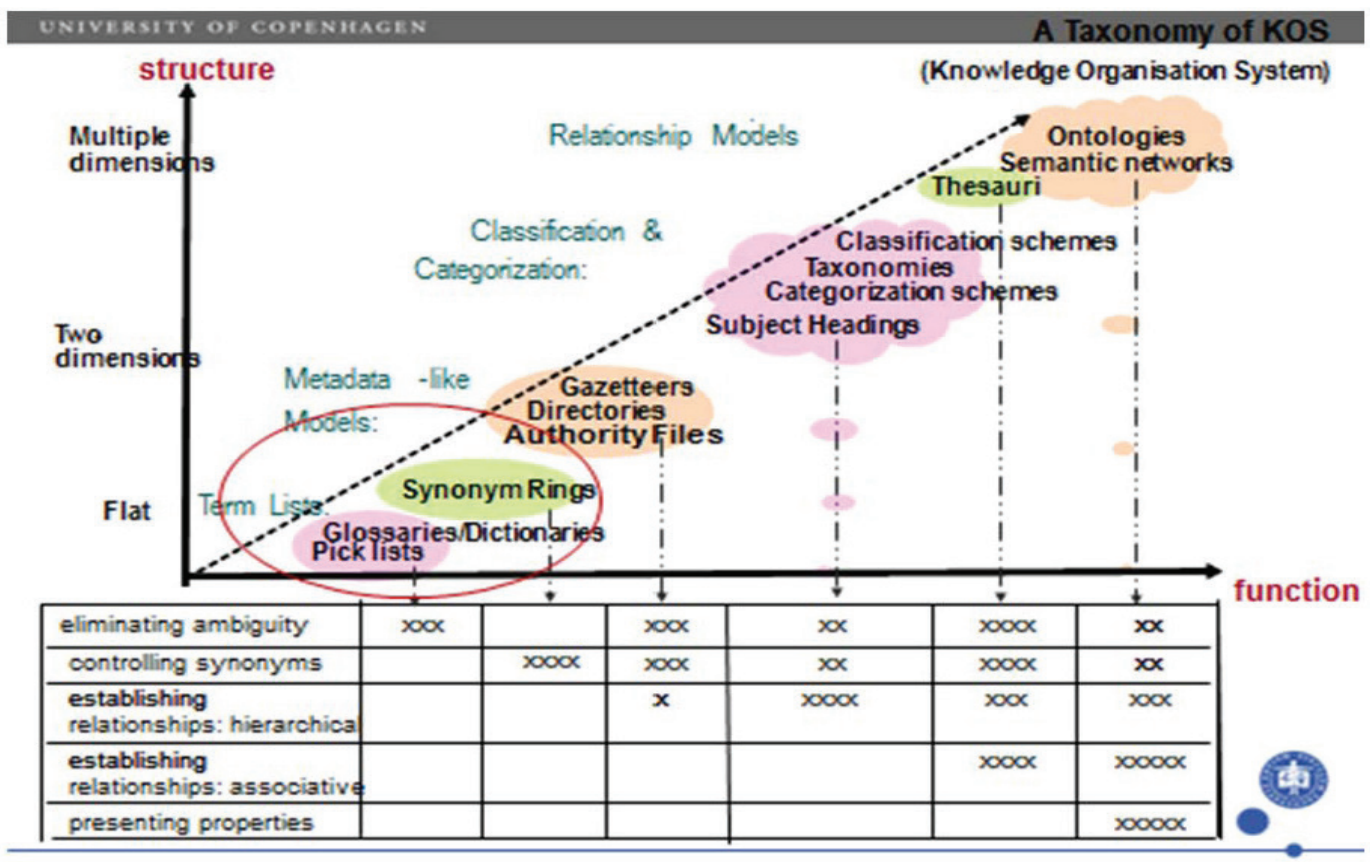

Figur 3. Strukturer og funktioner af forskellige taksonomier (Zeng, 2008, s. 161)

problemer i praksis, når brugerne kommer i tvivl om, hvilket ressort spørgsmålet hører under, og forvirring opstår især, når afdelingerne skifter navn.

Et diagram over Knowledge Organization Systems (KOS) viser de forskellige systemer, deres fordele og kompleksitet (figur 3). For at løse problemet, som WFPgo's konstruktion præsenterede, blev det foreslået at anvende Hedden's brede taksonomidefinition og mht. KOS at anvende den mindst strukturerede af taksonomierne nemlig en emneordsliste suppleret med synonymringe. Fordelene ved en emneordsliste og synonymringe er henholdsvis eliminering af begrebernes tvetydighed og kontrol af synonymer.

En kontrolleret emneordsliste (pick list) er en begrænset liste over emneord beregnet til et bestemt formål f.eks. indeksering eller kategorisering. Den er kontrolleret, fordi kun termer fra listen må bruges inden for et bestemt emneområde. Hvis den bliver anvendt af mere end en person, er den kontrollet idet den foreskriver, hvem der må anvende den og hvordan. Emneordslisten må gerne vokse, men kun under den definerede politik f.eks. fastsættelse af maksimum antal termer på listen. Målet med en kontrolleret emneordsliste er at sikre lighed i måden at tildele indekseringstermer på, at undgå tvetydighed af ter- merne og at sikre sig mod anvendelse af "forkerte" indekseringstermer.

For at få WFP's brugeres syn på HLT og anvendeligheden af samme ved strukturering af søgetermerne fra WFPgo til "navigational" web spørgsmål udvalgtes de 150 hyppigst forekommende søgestrenge fra log-filen i WFPgo's søgemaskine (samme log-fil som beskrevet tidligere). Søgestrengene blev renset for gentagelser (f.eks. hvor eneste forskel var brug af store eller små bogstaver) og flertal / ental endelser. Dette gav i alt 126 søgestrenge. Søgestrengene blev benyttet i en kortsorteringsøvelse i en workshop (WS1) med 27 deltagere . En kortsorteringsøvelse kan give indsigt i brugernes mentale modeller og understrege måderne, de ofte ubevidst (tacit) grupperer, sorterer og indekserer opgaver og arbejder på (Morville \& Rosenfeld, 2007, s. 255). Da vi her ønskede at undersøge, i hvor høj grad den foreslåede HLT kunne anvendes som organiserende ramme for de anvendte søgetermer, valgte vi at anvende en lukket kortsorteringsmodel, hvor den overordnede kategorisering var fastlagt i form af HLT-'en. Dette i modsætning til en åben kortsorteringsmodel hvor der ikke er defineret en overordnet kategorisering. Kortsorteringsøvelsen blev afviklet således, at vi gav deltagerne 126 kort med søgetermer og bad dem organisere 
disse under termerne i HLT'en, som var arrangeret på sedler på bordene foran grupperne.

Analysen af øvelsen viste, at HLT'en skulle revideres i forhold til implementering. Support function's termer, som var blevet præsenteret som aspekter, dvs. synsvinkler, blev af alle deltagere brugt som en del af HLT. Analysen af øvelsen viste, at HLT skulle udvides med "Support functions". De geografiske termer var ikke en del af HLT, hvilket var et problem for deltagerne. Analysen viste således, at de geografiske termer skulle inkorporeres som aspekter, der kunne tilføjes alle termerne i HLT. Et eksempel er "Administration \& Support" fra HLT som kan anskues geografisk og tildeles facetten Thailand eller Asien (figur 4).

På baggrund af workshoppen og analysen af resultaterne blev der formuleret en udvidelse til HLT'en. Den ændrede taksonomi skal inkludere "Operational Functions \& Themes" og "Support functions" og i tillæg geografiske aspekter. "Cross themes" skal bibeholdes i HLT, og nye temaer kan erstatte de gamle, hvis WFP finder det nødvendigt. Emneordslisten skal begrænses til 600-800 termer, som alle skal klassificeres under HLT.

Det ses ofte, at taksonomier bliver tilføjet informationsarkitekturen (strukturelt design), online informationsservicer, intranet indholdsorganisering og "corporate content management systems". I sådanne web-taksonomier er vægten på guidet brugernavigation mere end på søgning og genfinding af specifik information. Navigation betyder, at finde vej (Lin, DiCuccio, Grigoryan \& Wilbur, 2008) og i informationsvidenskab bliver det brugt som en metafor, hvor man bestemmer sin position og sin vej gennem begreber og dokumenter. Taksonomien til en webside minder om en indholdsfortegnelse organiseret efter emne. Den kan reflekteres i navigationsmenuen og i sideoversigten. Når dette forekommer kaldes det en navigationstaksonomi (Hedden, 2010, s. 22-23).

Søgelog-filen fra regionalkontorerne (spørgsmål stillet i september 2013) blev analyseret og de 1712 forespørgsler delt i navigations- og emnetermer.

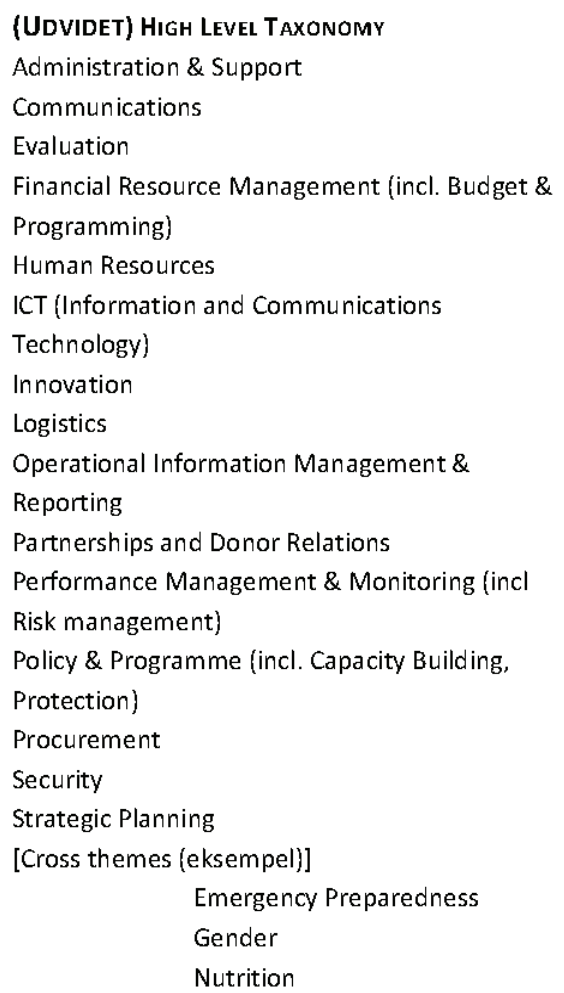

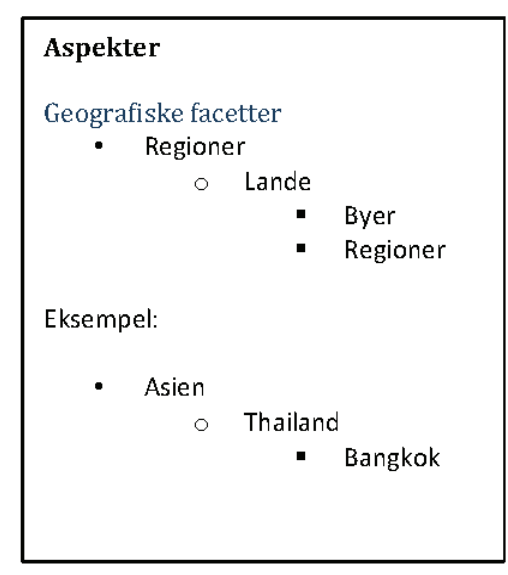


Navigationstermer forstås som:

1. informations behov som kan navigeres direkte til en side,

2. specifikke spørgsmål som indikerer et kendt svar f.eks. et sidenavn som 'COMET; compass; og EPIC', og

3. specifikke dokumenter f.eks. guides, checklister og manualer som 'UN exchange rate June 2013; administrative calendar; og appmr learning materials'.

Emnetermer udtrykkes som:

1. termer hvor brugeren er usikker på, hvad han/ hun leder efter, og

2. termer hvor brugeren er usikker på, hvad informationssystemet dækker.

De fundne navigationstermer kan anvendes i en emneordsliste (pick-list), de specifikke emnetermer kan benyttes til brug for dannelse af synonymringe (se nedenfor) med associerede termer.

\section{Etablering af synonymringe}

I nogle kontrollerede vokabularer er der et sæt af synonymer for alle begreber, dog sådan at der ikke er en foretrukket term. Denne type er kendt som synonymringe (synsets), fordi alle synonymer behandles ens og bliver udtrykt i en ring, hvor alle termer relaterer sig til hinanden. WordNet databasen over det engelske sprog arbejder med "cognitive syno- nyms (synsets)", som repræsenterer indholdsmæssige semantiske og leksikalske relationer. WordNet minder noget om en tesaurus, idet den grupperer ord sammen, baseret på deres betydning $\mathrm{i}$ et domæne (Princeton University, 2015). Et eksempel på en synonymring eller synsets med akronymopløsninger og relaterede akronymtermer findes i figur 5. Synonymringe anvendes, når en termliste ikke vises for brugerne, eller hvis brugeren benytter termerne via en søgeboks. Hvis synonymerne er skjult for brugerne, er distinktionen mellem foretrukne og ikke-foretrukne termer udvisket. Skønt disse typer af kontrollerede vokabularer er almindelige, er de ofte usynlige, så terminologien synonymring er ikke særlig kendt.

Deltagerne blev observeret under en af workshopøvelserne (WS2) med 27 deltagere, hvor de blev bedt om at konstruere "sande" (akronymer og deres opløsning), relaterede synonymringe og "foretrukne" synonymringe (baseret på spørgsmålene fra WFPgo fra september 2013). Deltagerne blev bedt om at vurdere deres nytteværdi ved søgninger. Vores observationer og de ansattes udsagn viste, at der var bred enighed om, at synonymringe gjorde komplicerede søgninger enklere, da bruger ikke behøvede at tænke på akronymer og deres opløsning eller typer af relaterede termer etc. (figur 6).

I 2013 håndterede WFP enorme akutte nødhjælpsprojekter i Syrien og på Filippinerne. For at vurdere om, der skulle etableres generelle, permanente synonymringe til brug for søgninger i forbindelse med nødhjælpsarbejde, blev spørgsmålene fra den

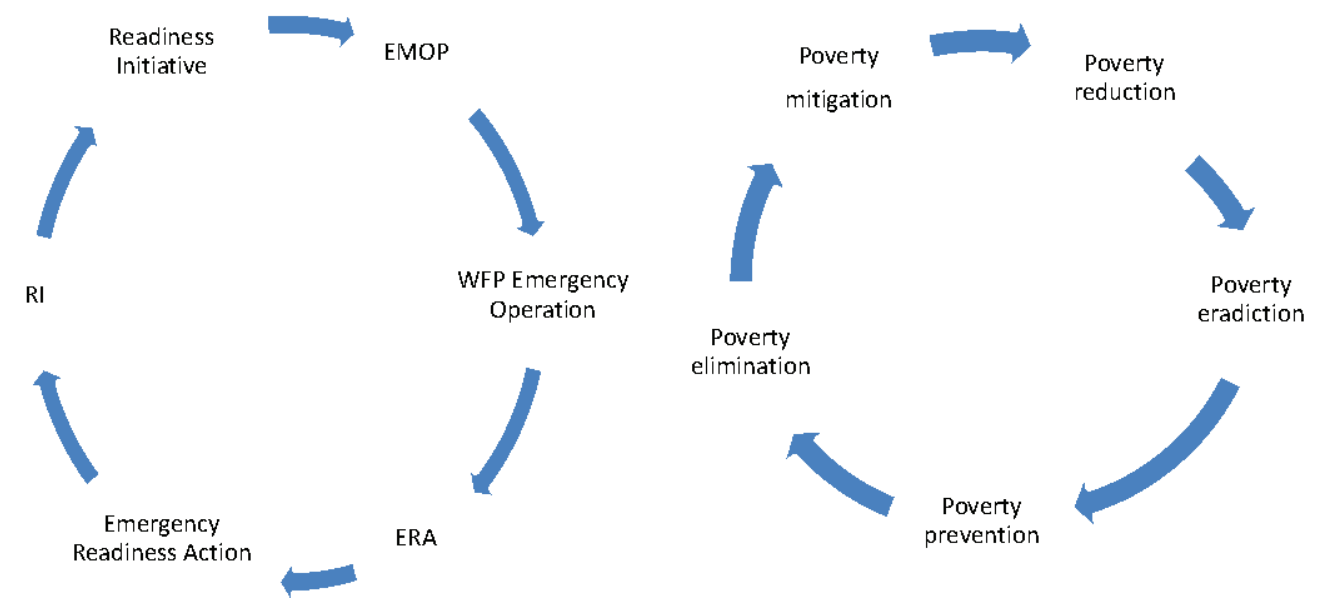

Figure 5. Synonymringe med akronymer og deres relationer Figur 6. Synonymring med associerede termer (Zeng, 2007) 
tremåneders log-fil fra hovedkvarteret i Rom og kontorene i Syrien og på Filippinerne analyseret. Ingen af søgningerne indikerede, at der var brugt en speciel "nødhjælpsterminologi". Grunden er formodentlig, at WFP's mål er at levere nødhjælp i form af mad til ofrene for naturkatastrofer, krig etc., derfor er terminologien $\mathrm{i}$ organisationen allerede rettet mod målet. Synonymringe for katastrofer blev derfor ikke foreslået, men hvis nødvendigheden viser sig, kan de hurtigt etableres.

\section{Organisation af fremtidigt taksonomiarbejde}

Det er evident, at forskellige kategorier af ansatte har forskellig viden og informationsbehov. Det betyder, at alle grupper af ansatte skal være i stand til at søge viden i forhold til deres specielle behov og ved hjælp af den/for dem bedst tænkelige teknologi. Imidlertid er det nødvendig at koordinere to centrale elementer: de ansattes vidensbehov skal kortlægges, og dernæst skal den faktuelle viden i organisationen identificeres.

Anbefalingerne er, at man etablerer en taksonomiadministrator i WFP. Denne person skal være ansvarlig for opbygning og vedligeholdelse af taksonomien (emneordslisten) og for udformning og kontrol af synonymringe. I tillæg skal der udnævnes "taksonomi-champions" $i$ alle afdelingerne og oprettes et taksonomi-netværk.

Taksonomi-champions skal analysere brugerbehov i deres respektive afdelinger. Alt efter kompleksiteten af taksonomiprojektet foreslår Pincher (2010), at antallet af taksonomi-champions skal være mellem seks og tolv med forskellige ekspertiser. Et andet kriterie for udvælgelsen skal være senioritet, således at personerne med vægt kan adressere ledelsen omkring beslutninger og godkendelse (ibid.).
Taksonomier kan ændre arbejdsbetingelserne ved f.eks. at kræve, at alle ansatte indekserer og uploader dokumenter til intranet systemet. Sådanne ændringer møder ofte modstand, og det er vigtigt at taksonomiadministratoren og - champions udvikler en strategi til at håndtere en mulig modstand. Målet er at holde alle involverede informerede om formålet med taksonomien og dens relevans, den anvendte metode samt udviklingen og forventningerne til de ansatte. Det kan gøres ved at involvere de ansatte i diskussionerne og ved at give dem mulighed for at fremsætte spørgsmål.

I WFP håndterer de ansatte allerede metadata (selvom terminologien er fremmed for dem). Kommentarer fra den sidste workshop (WS2) indikerede, at forslaget om en emneordsliste og synonymringe let kunne implementeres i stedet for den noget usystematiske kategorisering, som nu anvendes.

\section{Brugerønsker til forbedret søgefunktionalitet}

Som det fremgår af de afholdte brugerinterviews i fase 2 af case studiet var der stor utilfredshed med den eksisterende søgefunktion i WFPgo, hvilket resulterede i en grad af mistillid til systemet og tvivl i forhold til en effektiv måde at finde relevante dokumenter. Samtidigt gav respondenterne udtryk for en høj grad af skepsis i forhold til validiteten af de fremfundne dokumenter, da disse i mange tilfælde var forældede, eller fordi der fandtes flere versioner af samme dokument, og fordi det ikke var nyeste version af dokumentet, der blev vist først.

For at afdække brugernes ønsker til en forbedret søgemaskine og dens funktionalitet, blev der afholdt en workshop (WS3), hvor deltagerne formulerede deres ønsker til funktionaliteten i en søgemaskine. Workshoppen foregik gruppevis efter et fælles oplæg, hvor deltagerne blev givet en introduktion til centrale

\begin{tabular}{|l|l|l|}
\hline Indholdsobjekt & Eksempler & Uddybning \\
\hline Dokumenter & $\begin{array}{l}\text { Policy dokumenter } \\
\text { Best Practice dokumenter }\end{array}$ & Dokumenter fra Excecutive Board \\
\hline Information & Faktuel information & $\begin{array}{l}\text { Landeinformation } \\
\text { Retningslinjer (forretnings) Processer } \\
\text { Retningslinjer procedurer }\end{array}$ \\
\hline Ekspertinformation & Ekspertprofiler & Kontaktinformation \\
\hline
\end{tabular}

Tabel 4. Eksempler på indholdsobjekter som forventes $i$ systemet 


\begin{tabular}{|c|c|c|}
\hline Funktioner & Eksempler & Uddybning \\
\hline Kontekstrelateret & Personalisering & $\begin{array}{l}\text { Efter geografisk lokation } \\
\text { Personlige profiler }\end{array}$ \\
\hline Søgeformulering & $\begin{array}{l}\text { Stavekontrol } \\
\text { Ordforslag } \\
\text { Stemmesøgning } \\
\text { Naturligt sprog }\end{array}$ & $\begin{array}{l}\text { Landeinformation } \\
\text { Retningslinjer (forretnings) Processer } \\
\text { Retningslinjer procedurer }\end{array}$ \\
\hline $\begin{array}{l}\text { Visning af søgere- } \\
\text { sultater }\end{array}$ & $\begin{array}{l}\text { Centrale metadata } \\
\text { Kildeinformation } \\
\text { "Blended" resultater } \\
\text { 0-hits side }\end{array}$ & $\begin{array}{l}\text { Dokument titel, -ophav, organisatorisk enhed } \\
\text { etc. bør vises } \\
\text { Oplysninger om organisatorisk enhed vises } \\
\text { Integreret visning af søgeresultater fra for- } \\
\text { skellige informationssystemer } \\
\text { Skal udformes så brugeren hjælpes videre }\end{array}$ \\
\hline Facetteret søgning & Kategorisering & $\begin{array}{l}\text { Kategorier efter Informationstyper, doku- } \\
\text { menttyper, High level taxonomy, oprindeligt } \\
\text { informationssystem }\end{array}$ \\
\hline Social search & Deling af søgeresultater & \\
\hline Andet & $\begin{array}{l}\text { Søge historik } \\
\text { Aktiverede links / dokumenter }\end{array}$ & \\
\hline
\end{tabular}

Tabel 5. Brugerønsker til funktioner $i$ søgemaskine. Funktioner er de forskellig funktioner til filtrering $m v$ af søgeresultater der ønskes

aspekter af informationssøgeprocessen, søgemaskiners virkemåde, funktion af metadata i søgemaskiner samt manipulationsmåder i brugergrænsefladen. 4 grupper med i alt 24 deltagere på tværs af afdelinger medvirkede.

Resultatet af workshoppen kan opdeles i ønsker til indholdstyper og politikker for administration af disse samt ønsker til funktionaliteten af en forbedret søgemaskine.

Formulerede brugerønsker relateret til indholdsobjekter som forventes tilgængelige:

Udover de ovennævnte indholdsobjekter blev der også formuleret ønske om bedre dokumentstyring i form af en styrkelse af "content management" - processer således at forældet information/dokumenter undgås $\mathrm{og}$ at versionsstyring bør implementeres. I tabel 5 er de brugerønsker til optimering af søgemaskine som blev identificeret. Den anvendte opdeling er inspireret af Russell-Rose \& Tate (2013).

Som det fremgår af tabel 5 vil en fælles taksonomi understøtte en række af de formulerede ønsker til en forbedret søgemaskine. Muligheden for facetteret søgning efter kategorier kan nævnes som et eksem- pel. Udover brugerønsker nævnt i tabel 5 blev ønsket om adgang til dokumenter på tværs af eksisterende informationssystemer integreret $i$ en grænseflade understreget af deltagerne. Et af midlerne til at opnå dette vil være implementeringen af en fælles taksonomi.

\section{Konklusion}

Forskningsspørgsmålet "At betragte informationsarkitekturen for WFP på et overordnet organisatorisk plan, hvor det ikke kun indebærer at udvikle organisationssystemer og -strukturer for et intranet, men også at etablere en fælles terminologi og en virksomhedstaksonomi for hele organisationen" er blevet operationaliseret ved 3 undersøgelsesspørgsmål, som hver især bidrager til en mulig løsning af forskningsspørgsmålet.

En væsentlig mangel i WFP er, at der ikke eksisterer en fælles terminologi og en fælles forståelse i hele organisationen af KM og IM. For WFP kan det være interessant at få belyst, hvordan tilsvarende organisationer definerer og/eller beskæftiget sig med KM og IM. Det blev derfor besluttet at begynde med en dokumentarisk undersøgelse af forståelsen af de to begreber, for derefter at lave et meningskondenseren- 
de, kvalitativt interview med afdelingerne i WFP's hovedkvarter i Rom. Analysen viser, at forskellige organisationer som f.eks. Gartner Group, Verdensbankens og IFAD arbejder med uensartede KM strategier, hvor især forholdet til henholdsvis processer alene eller sammen med produkter varierer. Dette demonstrerer, at der heller ikke indenfor andre også fagligt beslægtede organisationer er fuld enighed om en fælles KM begrebsdefinition. Forståelsen af IM er også divergerende, idet IM, hvis vægten er lagt på teknologien, ses som en undergruppe til KM. Der er derfor behov for at skabe en fælles platform blandt de ansatte $\mathrm{i}$ WFP til håndtering af information og viden. Interviewene i de enkelte afdelinger viste, at WFP generelt er en organisation med meget lidt erfaring i systematisk KM og IM. Interviewene viste desuden, at de ansatte havde forskellige forståelser af KM og IM. I nogle afdelinger fokuserede de ansatte på enkelte dele af KM og IM, medens de i andre helt undlod at svare på spørgsmålet og i stedet pegede på nødvendigheden af at udvikle en fælles definition. Selvom interviewene er resumerende, er det generelle indtryk, at afdelingerne indbyrdes ikke har en fælles forståelse af KM og IM. Det må derfor anbefales, at WFP stræber mod en fælles definition af KM og IM og en fælles terminologipolitik. En udvikling af en "corporate information and knowledge management strategy" kræver, at der inden for organisationen anvendes samme terminologi.

Med udgangspunkt i TAM blev det klart, at brugerne af det eksisterende intranet WFPgo fandt systemet utilstrækkeligt, og at brugerne derfor til en hvis grad afviser at bruge systemet eller betragter systemets usefullnes og ease of use som værende lav. Der er en række årsager til dette herunder en dårligt fungerende informationsarkitektur inkluderende både problemer med eksisterende navigationsmuligheder suppleret af problemer med søgefunktionalitet. Desuden er den oplæring i systemer som brugerne tilbydes mangelfuld. Den dårligt fungerende navigationsstruktur blev understreget af resultaterne fra analysen af søgelog-filer, hvor mange søgninger har karakter af at træde i stedet for link-navigation. En sikring af fremfundne dokumenters aktualitet var også en grund til frustration.

Ud fra de formulerede brugerkrav til en forberedt søgefunktionalitet kan det konkluderes, at en optimeret adgang til dokumenter i de anvendte systemer og dermed på tværs af de etablerede informationssiloer er et ønske fra brugerne. For at opfylde dette vil det kræve, at en række forudsætninger opfyldes. Dette inkluderer ensartet indeksering af de dokumenter og indhold, der skal gøres tilgængelig på tværs af de forskellige systemer, en integration af søgningerne, samt en forbedret understøttelse af brugernes interaktion med søgesystemet. Dette indbefatter bl.a. overvejelser om, hvorledes søgeresultater skal præsenteres for brugerne, samt hvilke muligheder brugerne skal tilbydes for at manipulere et søgeresultat med anvendelse af f.eks. facetteret søgning mv.

Et redskab til at få en effektiv informationsarkitektur er at udvikle en række meta-data herunder en organisations- eller virksomhedstaksonomi. Med baggrund i WFP's værdikæde og de tilknyttede termer blev en HLT opstillet. Denne funktionsbaserede terminologi var tidligere blevet præsenteret på et ledelsesseminar. HLT'en og tilhørende termer blev introduceret på en workshop med repræsentanter for de forskellige afdelinger. En kortsorteringsøvelse gav et godt indblik i, hvordan de ansatte i WFP forstod HLT'en, og deltagerne anviste en række ændringer til taksonomistrukturen, ligesom de pegede på en antalsmæssigt begrænset emneordsliste til brug ved søgning. Afdelingerne blev introduceret til begrebet synonymringe, hvor synonymerne bliver udtrykt i en ring, hvorved alle termer relateres til hinanden. Ved søgning bliver dokumenter fremfundet uanset hvilken af termerne fra synonymringen, der står i dokumentet. De ansatte fandt, at synonymringe gjorde komplicerede søgninger enklere, og at de var et godt supplement til emneordslisten.

Ved analyse af 2013 log-filen for landekontorer på Filippinerne og i Syrien blev det undersøgt, om synonymringideen kunne anvendes til en speciel "nødhjælpsterminologi" for katastrofeområder. Dette kunne ikke påvises, og grunden er formodentlig, at WFP's mål er at levere nødhjælp, derfor er terminologien i organisationen allerede rettet mod dette mål.

Som et resultat af de afholdte workshops overvejer WFP at udvikle en taksonomi af en begrænset størrelse og med en "flad" struktur baseret på en emneordsliste og brug af synonymringe til "ægte" synonymer og associerede termer. For stadig at kunne udvikle taksonomien under kontrollerede former kan WFP ansætte en taksonomiadministrator centralt i Rom, som skal arbejde sammen med taksonomichampions, der er udpeget fra afdelinger i WFP i 
hovedkvarteret og på landekontorer. Denne konstruktion kan sikre, at fremtidigt taksonomiarbejde inkluderer slutbrugerne. WFP har fulgt forslaget og ansat en taksonomiadministrator, ligesom afdelingerne er i gang med at udpege taksonomi-champions.

Organisationer synes at udvikle sig, hvis de anvender viden $i$ alle processer, øger de ansattes arbejdsforståelse og udvikler et taksonomiværktøj. Imidlertid er en fremtidig evaluering nødvendig og vil forhåbentlig give en dybere forståelse af, om de foreslåede initiativer har løst informationsarkitekturproblemerne i WFP.

\section{Note}

1. Gartner, Inc. is the world's leading information technology research and advisory company http:// www.gartner.com/technology/about.jsp

Tak til Signe Helms Ratjen og Stine Netman for hjælp ved gennemførelse af interviews med WFP personale. Case studiet blev i 2015 udvalgt som en impact case fra det Humanitiske Fakultet. Impact casene findes beskrevet i Københavns Universitet. Det Humanitiske Fakultet (2015) Humanioras impact. 11 eksempler på, hvordan humanistisk forskning påvirker og bidrager til samfundet. Lokaliseret 16.11.2015 på http://hum.ku.dk/samarbejde/IMPACT_web.pdf

\section{Referencer}

American Productive and Quality Center (APQC) (2010). The World Bank: Building and Sustaining Communities of Practice. Houston : APQC. Lokaliseret 1.10.2015 på: ftp://public.dhe.ibm.com/services/us/gbs/bus/hcm/rbtt/worldbank.pdf

Bawden, D \& Robinson, L (2012). Introduction to Information Science. London: Facet Publishing.

Broder, A (2002). A taxonomy of web search. SIGIR Forum, Fall 2002, 36(2). Lokaliseret 20.5.2015 på WWW: http://www.sigir.org/forum/F2002/broder. pdf

Chaudhry, AS \& Jiun, TP (2005). Enhancing access to digital information resources on heritage. Journal of Documentation, 61(6), 751-776.
Davenport, TH (1994). Saving IT's Soul: Human Centered Information Management. Harvard Business Review, March-April, 72(2), 119-131.

Davis, FD (1989). Pervieved Usefulness, Percieved Ease of Use, and User Acceptance. MIS Quarterly, 13(3), 319-340.

Duhon, B (1998). It's All in our Heads. Inform, September, 12(8).

Evers, H (2009). The documentary method in intercultural research scenarios. FQS. Forum: Qualitative social research, 10(1). Lokaliseret 22.10.2015 på WWW: http://www.qualitative-research.net/index. php/fqs/article/viewArticle/1245/2707

Gartner IT Glossary (2015). Lokaliseret 1.10.2015 på WWW: http://www.gartner.com/it-glossary/kmknowledge-management

Gartner IT Glossary (2015). Lokaliseret 1.10.2015 på WWW: http://www.gartner.com/it-glossary/iminformation-management

Gilchrist, A (2001). Corporate taxonomies: report on a survey of current practice. Online Information Review, 25 (2), $94-103$.

Gilchrist, A (2003). Thesauri, taxonomies and ontologies - an etymological note. Journal of Documentation, 59(1), 7-18.

Hyldegård, J., Lund, H, Moring, C, Pors, NO \& Schreiber, T. (2011). Studerende. Laering og webtutorials: en analyse af 3 norske lceringssystemer. Det Informationsvidenskabelige Akademi. Lokaliseret 9.11.2015 på WWW: http://curis.ku.dk/ws/files/47072681/Studerende_1_ring_og_webtutorials. pdf

Hedden, H (2010). The Accidental Taxonomist. Medford : Information Today Inc.

Howe, D (2010). Computing dictionary. Lokaliseret 20.5.2015 på WWW: http://dictionary.reference. $\mathrm{com} /$ browse/information+management

Informationsordbogen: ordbog for informationshåndtering, bog og bibliotek. (u.d.). Lokaliseret 
20.5.2015 på WWW: http://www.informationsordbogen.dk/concept.php?cid=904

International Fund for Agricultural Development (IFAD) (2007). Knowledge management strategy. IFAD : Rome. Lokaliseret 1.10.2015 på WWW: http://www.ifad.org/pub/policy/km/e.pdf

International Fund for Agricultural Development (IFAD) (2011). Knowledge Management and Communication Strategy. Indonesia 20122013.IFAD : Indonesia. Lokaliseret 1.10.2015 på WWW: http://www.ruralpovertyportal.org/documents/654016/690745/DLFE-3828.pdf/a3781329d19b-44ea-9179-0eea7f58c081?version $=1.0$

Jansen, BJ (2009). Understanding User-Web Interactions via Web Analysis. San Rafael: Morgan \& Claypool.

Koenig, ME (2012). What is KM? Knowledge Management Explained. KMWorld Content, Document and Knowledge Management. Lokaliseret 20.5.2015 på WWW: http://www.kmworld.com/Articles/Editorial/What-Is-.../What-is-KM-Knowledge-Management-Explained-82405.aspx

Kvale, S \& Brinkmann,S (2009). Interviews : an introduction to qualitative research interviewing, Sage Publications.

Lazar, J, Feng, H \& Hochheiser, H (2010). Research Methods in Human-Computer Interaction. United Kingdom : John Wiley \& Sons Ltd.

Lin, J, DiCuccio, M, Grigoryan, V \& Wilbur, WJ (2008). Navigating information spaces: A case study of related article search in PubMed. Information Processing \& Management, 44(5), 1771-1783.

Morville, P \& Rosenfeld, L (2007). Information Architecture for the World Wide Web, 3rd Ed. Sebastopol : O'Reilly Media, Inc.
O'Leary, DE (2008). A multilingual knowledge management system: A case study of FAO and WAICENT. Decision Support Systems, 45(3), 641661. Lokaliseret 1.10.2015 på WWW: http://ccc.inaoep.mx/ villasen/bib/A\%20multilingual $\% 20$ knowledge $\% 20$ management $\% 20$ system.pdf

Pincher, M (2010). A Guide to Developing Taxonomies for Effective Data Management. Computer Weekly, 8 March. Lokaliseret 22.11.2015 på WWW: http://www.computerweekly.com/ Articles/2010/04/06/240539/A-guide-to-developingtaxonomies-for-effective-data.htm

Princeton University (2015). About WordNet. WordNet. Princeton University. . Lokaliseret 12.10.2015 på: http://wordnet.princeton.edu

Rosenfeld, L (2011). Search analytics for your site: Conversations with your customers. New York : Rosenfeld Media

Russell-Rose, T \& Tate, T (2013) Designing the search experience : the information architecture of discovery. Amsterdam : Morgan Kaufmann.

Venkatesh, V \& Davis, FD (2000). A theoretical extension of the technology acceptance model : four longitudinal field studies. Management Science, 46(2), 186-204.

Zeng, ML (2005), Introductory Review of Current Knowledge Organization Systems/Structures/Services (KOS), Second International Seminar on Subject Access to Information. Helsinki, Finland, 29-30 November 2007.

Zeng, ML (2008). Knowledge Organization Systems (KOS). Knowledge Organization, 35(2/3), 160-182. 